\title{
FORMULATION AND EVALUATION OF BILAYER TABLETS OF BACLOFEN USING SYNTHETIC POLYMERS
}

\author{
*P.K. Makwana, K.B. Patel, J.R. Vyas, Umesh M Upadhyay
}

Department of Pharmaceutics,Sigma Institute of Pharmacy, Bakrol, Vadodara, Gujarat, India.

Received 12 March 2015; Review Completed 08 April 2015; Accepted 02 May 2015, Available online 15 May 2015

\begin{abstract}
Aim of study was to develop bilayer drug delivery for treatment of spasticity by delivering loading and maintenance dose for fast achievement of peak plasma concentration and maintaining the same respectively. The prepared drug loaded bilayer tablets were evaluated for pre and post compression parameters. Stability study of the promising formulation was also performed. The tablets were prepared by direct compression and wet granulation method. The loading dose was delivered in the form of immediate release layer prepared by different super-disintegrations and maintenance dose was delivered through sustained release layer prepared by using polymers like HPMC K4, HPMC K15M, HPMC K100, PEO WSR 303 and Precirol. Both the immediate release layer and sustained release layers were separately optimized and then combined to optimize the bilayertablets. No interactions were found between drug and excipients. Formulation containing Kyron T314 shows immediate drug release. Formulation Containing PEO WSR 303 shows sustained release action and bilayer formulations F6 shows releases up to 24 hours. Bilayer tablets with release characteristics offer critical advantages such as, site specificity with improved absorption and efficacy.
\end{abstract}

Key words: Baclofen, Bilayer tablet, sustain release tablet

\section{INTRODUCTION:}

Oral route is the most commonly employed route of drug administration. Although different Route of administration are used for the delivery of drugs, oral route remain the preferred mode. The popularity of the oral route is attributed patient acceptance, ease of administration, accurate dosing, cost effective manufacturing method and generally improved shelflife of the product. Even for sustained release systems the oral route of administration has been investigated the most, because of flexibility in dosage forms design that the oral route offers. With many drugs, the basic goal of therapy is to achieve a steady-state blood level or tissue level that is therapeutically effective and nontoxicfor an extended period of time. ${ }^{1-4}$

Bi-layer tablet concept has long been utilized to develop sustained released formulation. Such

Tablet has a fast releasing layer and may contain one (bi-layer), to sustain the drug release. The pharmacokinetic advantage relies on the criterion that, drug release from the fast releasing layer leads to a sudden rise in the blood concentration. However the blood level is maintained at steady state as the release from sustaining layer. ${ }^{5-8}$

Baclofen is structural analogue of gamma-amino butyric acid is a centrally acting skeletal muscle relaxant, which is widely used in the treatment of spasticity resulting from multiple sclerosis, muscle spasms, muscular rigidity and spinal cord injuries. ${ }^{9,10}$
Baclofen is rapidly absorbed from gastrointestinal tract and the peak plasma concentration is achieved within about $2 \mathrm{hr}$. It is largely excreted in the urine, $80 \%$ as unchanged drug and, the rest as metabolites. The elimination half-life has been reported to be $4 \mathrm{hr}$ and thus make it a potent candidate for sustained release dosage form. ${ }^{11,12}$<smiles>NCC(CC(=O)O)c1ccc(Cl)cc1</smiles>

Figure 1: Structure of baclofen

Chemical name: 4-Amino-3(p-chlorophenyl) butyric acid

*Address for correspondence Priti Makwana,

Department of Pharmaceutics, Sigma Institute of Pharmacy, Bakrol, Vadodara, Gujarat, India. Email:pritimakwana1991@gmail.com Mob. No: - +91-9408761280 


\section{Mechanism of action:}

Baclofenis is a structural analogue of g-amino butyric acid (GABA). Baclofen decreases spasticity by binding to $\mathrm{GABAB}$ receptors on presynaptic terminals of spinal interneurons. Binding to presynaptic $\mathrm{GABAB}$ receptors results in hyperpolarization of the membrane, which reduces $\mathrm{Ca}++$ influx and decreases the release of the excitatory neurotransmitters, glutamate, and aspartate. ${ }^{13}$

\section{MATERIALS:}

Baclofen was obtained as gift sample from Unicure Pvt.remedies, Vadodara. SSG, Crospovidon, CrossCarmellose and Kyron T 314 were obtained as gift sample from colorcon, Goa. HPMC grades, ethyl cellulose, Carbopol 934, PVP K-30, Mannitol, and Magnesiumstearate, Talc were procured commercially from chem dyes corporation Vadodara.Precirol ATO 5 was gift sample from GATTEFOSSÊ S.A.S., Mumbai, India, and PEO WSR 303 was gift sample from colorcon, Goa.

\section{METHOD OF PREPARATION:}

Direct compression was used for preparation of the immediate release layer and wet granulation technology was used for Sustained release layer containing baclofen. For both the layer, granulation was carried out separately, as follows:

\section{Preparation of immediate release layer (IR)}

All the ingredients were accurately weighed and passed through mesh 60\#.In order to mix the ingredients thoroughly drug, superdisintegrant, microcrystalline cellulose, magnesium stearate and talc were mixed in a mortar and pestle. The powder was passed through 60\# sieve and compressed on rotary tablet punching machine. (Made- Krishna Engineering)

\section{Preparation of sustained release layer (SR)}

It was performed by wet granulation method. The required amount of sustained release polymer were blended with baclofen and passed through 80 mesh sieve. Binding solution was prepared by dissolving required amount of PVP k 30 in iso propyl alcohol (IPA).Blended powders were granulated with IPA solution and sieved using 40 mesh sieves. The granules were dried at $45^{\circ} \mathrm{c}$ for $30 \mathrm{~min}$ in tray dryer to evaporate the IPA and then lubricated with required amount of talc, magnesium stearate, store the lubricated granules with suitable label till it's further used.

\section{Final compression of bilayer tablets}

Bilayer tablets were prepared by feeding $200 \mathrm{mg}$ of SR granules manually into punch and compressed them with pre compression force. Then $100 \mathrm{mg}$ of IR granules were manually fed into same die cavity SR granules and applied final compression force into rotary tablet punching machine.

\section{Evaluation parameter}

\section{Physical appearance}

All the immediate and sustained release tablets were visually inspected for any tablet defects like capping, lamination, presence of any coloured particle.

\section{Hardness}

This can be determined by using Monsanto hardness tester.

\section{Friability}

Friability can be measured by Roche friability tester. 10 tablets are kept in the friability tester and it is rotated at $25 \mathrm{rpm}$ for 4 minutes. Initial and final weights are then recorded and friability is calculated by following formula.

$$
\% \mathrm{~F}=[1-(\mathrm{Wt} / \mathrm{W})] * 100
$$

$\mathrm{W}$ - Initial weight of tablet

Wt- Weight of tablet after revolution.

If $\%$ Friability of tablets is less than $1 \%$ is considered acceptable.

\section{Weight variation test}

Weight variation test can be done as per the Indian Pharmacopoeia. 20 tablets were generally taken and were weighed individually and the weight variation was calculated with the use of standard deviation.

\section{In Vitro drug release studies:}

In Vitro drug release studies were performed using USP dissolution test apparatus (Type 1). The dissolution studies were performed in $900 \mathrm{ml}$ of dissolution medium which was stirred at $50 \mathrm{rpm}$ at $37 \pm 0.5^{\circ} \mathrm{C}$ following a $\mathrm{pH}$ progression method. i.e. $\mathrm{pH} 1.2$ for first $2 \mathrm{~h}, \mathrm{pH} 6.8$ for $24 \mathrm{hr}$. Aliquots was withdrawn periodically and replaced with fresh medium. 


\section{FORMULATION}

Table 1: Composition of immediate release layer tablet

\begin{tabular}{|c|c|c|c|c|}
\hline \multicolumn{5}{|c|}{ Immediate release layer } \\
\hline & F1(mg) & F2(mg) & F3(mg) & F4(mg) \\
\hline Baclofen & 5 & 5 & 5 & - \\
\hline Cros Povidone & 2 & - & - & - \\
\hline Cross Carmellose & - & 2 & - & 2 \\
\hline SSG & - & - & 90 & 90 \\
\hline Kyron T 314 & 90 & 90 & 2 & 2 \\
\hline MCC & 2 & 2 & 1 & 1 \\
\hline Mg Stearate & 1 & 1 & 100 & 100 \\
\hline Talc & 100 & 100 & & \\
\hline Total & & & & \\
\hline
\end{tabular}

Table 2: Composition of immediate release layer tablet

\begin{tabular}{|c|c|c|c|c|}
\hline \multicolumn{3}{|c|}{ Immediate release layer } & F7(mg) \\
\hline Baclofen & F5(mg) & F6(mg) & 5 & 5 \\
\hline Cros Povidone & 5 & 5 & - & - \\
\hline Cross Carmellose & 5 & - & - & - \\
\hline SSG & - & - & 5 & 5 \\
\hline Kyron T 314 & 87 & 87 & 2 & 87 \\
\hline MCC & 2 & 2 & 1 & 2 \\
\hline Mg Stearate & 1 & 1 & 100 & 1 \\
\hline Talc & 100 & 100 & & \\
\hline Total & & & & \\
\hline
\end{tabular}

Table 3: Composition of sustained release layertablet

\begin{tabular}{|c|c|c|c|c|c|c|}
\hline \multicolumn{7}{|c|}{ Sustained release layer } \\
\hline & F1(mg) & F2(mg) & F3(mg) & F4(mg) & F5(mg) & F6(mg) \\
\hline Baclofen & 21 & 21 & 21 & 21 & 21 & 21 \\
\hline HPMC K4 M & 60 & - & - & - & - & - \\
\hline HPMC K15 M & - & 60 & - & - & - & - \\
\hline HPMC K 100 M & - & - & 60 & - & - & - \\
\hline PEO WSR 303 & - & - & - & 20 & 40 & 60 \\
\hline PVP K 30 & 10 & 10 & 10 & 10 & 10 & 10 \\
\hline $\mathrm{DCP}$ & 103 & 103 & 103 & 143 & 123 & 103 \\
\hline Magnesium Stearate & 4 & 4 & 4 & 4 & 4 & 4 \\
\hline Talc & 2 & 2 & 2 & 2 & 2 & 2 \\
\hline IPA & q.s & q.s & q.s & q.s & q.s & q.s \\
\hline Total & 200 & 200 & 200 & 200 & 200 & 200 \\
\hline
\end{tabular}


Table 4: Composition of sustained release layertablet

\begin{tabular}{|c|c|c|c|c|c|c|c|c|c|}
\hline \multicolumn{19}{|c|}{} & $\begin{array}{c}\text { F7 } \\
(\mathbf{m g})\end{array}$ & $\begin{array}{c}\text { F8 } \\
(\mathbf{m g})\end{array}$ & $\begin{array}{c}\text { F9 } \\
(\mathbf{m g})\end{array}$ & $\begin{array}{c}\text { F10 } \\
(\mathbf{m g})\end{array}$ & $\begin{array}{c}\mathbf{F 1 1} \\
(\mathbf{m g})\end{array}$ & $\begin{array}{c}\mathbf{F 1 2} \\
(\mathbf{m g})\end{array}$ & $\begin{array}{c}\mathbf{F 1 3} \\
(\mathbf{m g})\end{array}$ & $\begin{array}{c}\text { F14 } \\
(\mathbf{m g})\end{array}$ & $\begin{array}{c}\mathbf{F 1 5} \\
(\mathbf{m g})\end{array}$ \\
\hline Baclofen & 21 & 21 & 21 & 21 & 21 & 21 & 21 & 21 & 21 \\
\hline Ethyl cellulose & 20 & 40 & 60 & - & - & - & - & - & - \\
\hline Carbopol & - & - & - & 10 & 20 & 40 & - & - & - \\
\hline Precirol & - & - & - & - & - & - & 40 & 60 & 80 \\
\hline PVP K 30 & 10 & 10 & 10 & 10 & 10 & 10 & 10 & 10 & 10 \\
\hline DCP & 143 & 123 & 103 & 153 & 143 & 123 & 123 & 103 & 83 \\
\hline Mg. Stearate & 4 & 4 & 4 & 4 & 4 & 4 & 4 & 4 & 4 \\
\hline Talc & 2 & 2 & 2 & 2 & 2 & 2 & 2 & 2 & 2 \\
\hline IPA & q.s & q.s & q.s & q.s & q.s & q.s & q.s & q.s & q.s \\
\hline Total & 200 & 200 & 200 & 200 & 200 & 200 & 200 & 200 & 200 \\
\hline
\end{tabular}

\section{RESULT:}

The results of evaluation parameters of formulations F1-F8 were calculated and described in this.
Precompression parameters such as Angle of Repose, Loose Bulk Density, Tapped Bulk Density, Hausner's

Ratio, and Carr's Index. Values are listed in Table 5.

Table 5: Pre compression study of immediate release layer tablets

\begin{tabular}{|c|c|c|c|c|c|}
\hline Batches & $\begin{array}{c}\text { Bulk Density } \\
\text { gm. } \mathrm{cm}^{-3}( \pm \text { S.D }) \\
(\mathrm{n}=3)\end{array}$ & $\begin{array}{l}\text { Tapped density } \\
\text { gm. } \mathrm{cm}^{-3}( \pm \text { S.D }) \\
(\mathrm{n}=3)\end{array}$ & $\begin{array}{c}\text { Carr's Index }( \pm \\
\text { S.D) } \\
(\mathbf{n}=\mathbf{3})\end{array}$ & 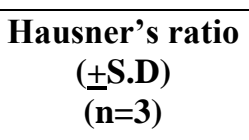 & $\begin{array}{c}\text { Angle of repose } \\
\qquad \begin{array}{c}\left(\Theta^{0}\right)( \pm S . D) \\
(n=3)\end{array}\end{array}$ \\
\hline $\mathrm{F} 1$ & $0.29 \pm 0.058$ & $0.36 \pm 0.07$ & $12.1 \pm 0.12$ & $1.13 \pm 0.22$ & $28.45 \pm 0.02$ \\
\hline $\mathrm{F} 2$ & $0.30 \pm 0.06$ & $0.33 \pm 0.06$ & $9.09 \pm 0.18$ & $1.11 \pm 0.222$ & $27.36 \pm 0.01$ \\
\hline F3 & $0.33 \pm 0.066$ & $0.4 \pm 0.08$ & $17.5 \pm 0.01$ & $1.21 \pm 0.24$ & $30.49 \pm 0.05$ \\
\hline F4 & $0.24 \pm 0.048$ & $0.43 \pm 0.086$ & $14.5 \pm 0.11$ & $1.18 \pm 0.23$ & $31.27 \pm 0.03$ \\
\hline F5 & $0.29 \pm 0.058$ & $0.31+0.062$ & $12.1 \pm 0.08$ & $1.13 \pm 0.22$ & $30.72 \pm 0.02$ \\
\hline F6 & $0.30 \pm 0.06$ & $0.37 \pm 0.074$ & $6.09 \pm 0.09$ & $1.14+0.23$ & $29.45 \pm 0.06$ \\
\hline F7 & $0.35 \pm 0.07$ & $0.48+0.096$ & $17.5 \pm 0.16$ & $1.24 \pm 0.25$ & $28.12 \pm 0.01$ \\
\hline F8 & $0.33 \pm 0.066$ & $0.4 \pm 0.08$ & $16.3 \pm 0.13$ & $1.20 \pm 0.24$ & $30.80 \pm 0.08$ \\
\hline
\end{tabular}

Table 6: Pre compression study of sustained release layer tablets

\begin{tabular}{|c|c|c|c|c|c|}
\hline Batches & $\begin{array}{c}\text { Bulk Density } \\
\text { gm cm }^{-3}( \pm \text { S.D } \\
(n=3)\end{array}$ & $\begin{array}{c}\text { Tapped density } \\
\operatorname{gm~cm}^{-3}( \pm \text { S.D }) \\
(n=3)\end{array}$ & $\begin{array}{c}\text { Carr's Index ( } \pm \\
\text { S.D) } \\
(\mathbf{n}=3)\end{array}$ & $\begin{array}{c}\text { Hausner's ratio } \\
(\underline{+ \text { S.D })} \\
(\mathbf{n}=3)\end{array}$ & $\begin{array}{c}\text { Angle of repose } \\
\left(\Theta^{\circ}\right)( \pm \text { S.D }) \\
(n=3)\end{array}$ \\
\hline F1 & $0.24 \pm 0.04$ & $0.63 \pm 0.12$ & $15.85 \pm 0.12$ & $1.18 \pm 0.23$ & $29.19 \pm 0.02$ \\
\hline F2 & $0.28 \pm 0.05$ & $0.62 \pm 0.124$ & $17.74 \pm 0.18$ & $1.21 \pm 0.24$ & $29.65 \pm 0.05$ \\
\hline F3 & $0.30 \pm 0.06$ & $0.54 \pm 0.108$ & $21.62 \pm 0.04$ & $1.19 \pm 0.23$ & $27.34 \pm 0.42$ \\
\hline F4 & $0.29 \pm 0.058$ & $0.64 \pm 0.128$ & $14.06 \pm 0.05$ & $1.16 \pm 0.232$ & $29.62 \pm 0.31$ \\
\hline F5 & $0.32 \pm 0.064$ & $0.52 \pm 0.10$ & $20.63 \pm 0.07$ & $1.26 \pm 0.25$ & $28.51 \pm 0.25$ \\
\hline F6 & $0.38 \pm 0.07$ & $0.58 \pm 0.11$ & $17.74 \pm 0.01$ & $1.21 \pm 0.24$ & $27.19 \pm 0.43$ \\
\hline F7 & $0.34 \pm 0.068$ & $0.62 \pm 0.12$ & $19.62 \pm 0.21$ & $1.20 \pm 0.24$ & $28.37 \pm 0.67$ \\
\hline F8 & $0.40+0.066$ & $0.58 \pm 0.11$ & $22.66 \pm 0.08$ & $1.15 \pm 0.23$ & $26.34 \pm 0.26$ \\
\hline F9 & $0.48 \pm 0.09$ & $0.62 \pm 0.12$ & $21.62 \pm 0.07$ & $1.28 \pm 0.25$ & $25.26 \pm 0.05$ \\
\hline F10 & $0.31+0.062$ & $0.54 \pm 0.10$ & $18.53 \pm 0.11$ & $1.12 \pm 0.22$ & $29.57 \pm 0.91$ \\
\hline F11 & $0.42 \pm 0.084$ & $0.46 \pm 0.09$ & $20.12 \pm 0.07$ & $1.24 \pm 0.25$ & $30.12 \pm 0.02$ \\
\hline F12 & $0.37 \pm 0.074$ & $0.48 \pm 00.096$ & $16.61 \pm 0.05$ & $1.14 \pm 0.23$ & $24.28 \pm 0.85$ \\
\hline F13 & $0.35 \pm 0.07$ & $0.44 \pm 0.08$ & $11.23 \pm 0.13$ & $1.18 \pm 0.23$ & $30.64 \pm 0.12$ \\
\hline F14 & $0.32 \pm 0.064$ & $0.50 \pm 0.1$ & $15.67 \pm 0.04$ & $1.15 \pm 0.23$ & $31.05 \pm 0.21$ \\
\hline F15 & $0.47 \pm 0.09$ & $0.51 \pm 0.10$ & $16.67 \pm 0.15$ & $1.14 \pm 0.22$ & $29.42 \pm 0.88$ \\
\hline
\end{tabular}


The results of evaluation parameters of formulations F1-F15 were calculated and described in this. Precompression parameters such as Angle of Repose, Loose Bulk Density, Tapped Bulk Density, Hausner's Ratio, and Carr's Index. Values are listed in Table 6. It was found that granules of all batched of wet granulation were found having fair-passable flow property.

The result of post compression evaluation parameters of formulations F1-F15 such as hardness, friability, weight variation and drug content is given in table no 7.

Table 7: Post compression study of bilayer layer tablet

\begin{tabular}{|c|c|c|c|c|}
\hline Batches & $\begin{array}{c}\text { Hardness }\left(\mathbf{k g ~ c m}^{-2} \pm\right. \\
\text { S.D) }(\mathbf{n = 3})\end{array}$ & Friability (\%) & $\begin{array}{c}\text { Weight variation Avg } \\
\text { weight }(\mathbf{m g})(\mathbf{S . D} \leq \mathbf{1 0 \%})\end{array}$ & $\begin{array}{c}\text { \% Drug Content } \\
\text { (S.D) }\end{array}$ \\
\hline F1 & $6 \pm 0.42$ & $0.61 \pm 0.12$ & $300 \pm 0.04$ & $100 \pm 0.01$ \\
\hline F2 & $5 \pm 0.39$ & $0.66 \pm 0.13$ & $301 \pm 0.09$ & $101 \pm 0.08$ \\
\hline F3 & $7 \pm 0.35$ & $0.38 \pm 0.07$ & $300 \pm 0.10$ & $101 \pm 0.10$ \\
\hline F4 & $6 \pm 0.46$ & $0.33 \pm 0.06$ & $301 \pm 0.14$ & $99.98 \pm 0.15$ \\
\hline F5 & $7 \pm 0.50$ & $0.26 \pm 0.05$ & $299 \pm 0.18$ & $98.87 \pm 0.17$ \\
\hline F6 & $5 \pm 0.59$ & $0.37 \pm 0.07$ & $304 \pm 0.13$ & $100 \pm 0.09$ \\
\hline F7 & $7 \pm 0.46$ & $0.49 \pm 0.09$ & $301 \pm 0.43$ & $99.52 \pm 0.13$ \\
\hline F8 & $6 \pm 0.57$ & $0.20 \pm 0.04$ & $298.8 \pm 0.36$ & $99.48 \pm 0.11$ \\
\hline F9 & $7 \pm 0.62$ & $0.57 \pm 0.11$ & $297 \pm 0.21$ & $97.39 \pm 0.04$ \\
\hline F10 & $5 \pm 0.21$ & $0.36 \pm 0.07$ & $300 \pm 0.38$ & $99.19 \pm 0.17$ \\
\hline F11 & $6 \pm 0.53$ & $0.29 \pm 0.05$ & $301 \pm 0.09$ & $100 \pm 0.15$ \\
\hline F12 & $7 \pm 0.60$ & $0.64 \pm 0.12$ & $299.8 \pm 0.9$ & $100 \pm 0.06$ \\
\hline F13 & $7 \pm 0.76$ & $0.52 \pm 0.10$ & $299.6 \pm 0.38$ & $99.53 \pm 0.25$ \\
\hline F14 & $5 \pm 0.66$ & $0.41 \pm 0.08$ & $300 \pm 0.44$ & $99.89 \pm 0.12$ \\
\hline F15 & $7 \pm 0.95$ & $0.50 \pm 0.1$ & $301 \pm 0.32$ & $99.54 \pm 0.24$ \\
\hline
\end{tabular}

In-Vitro Drug Release data of batch F1 to F15 were shown in figures given below.

\section{In Vitro Dissolution Study}

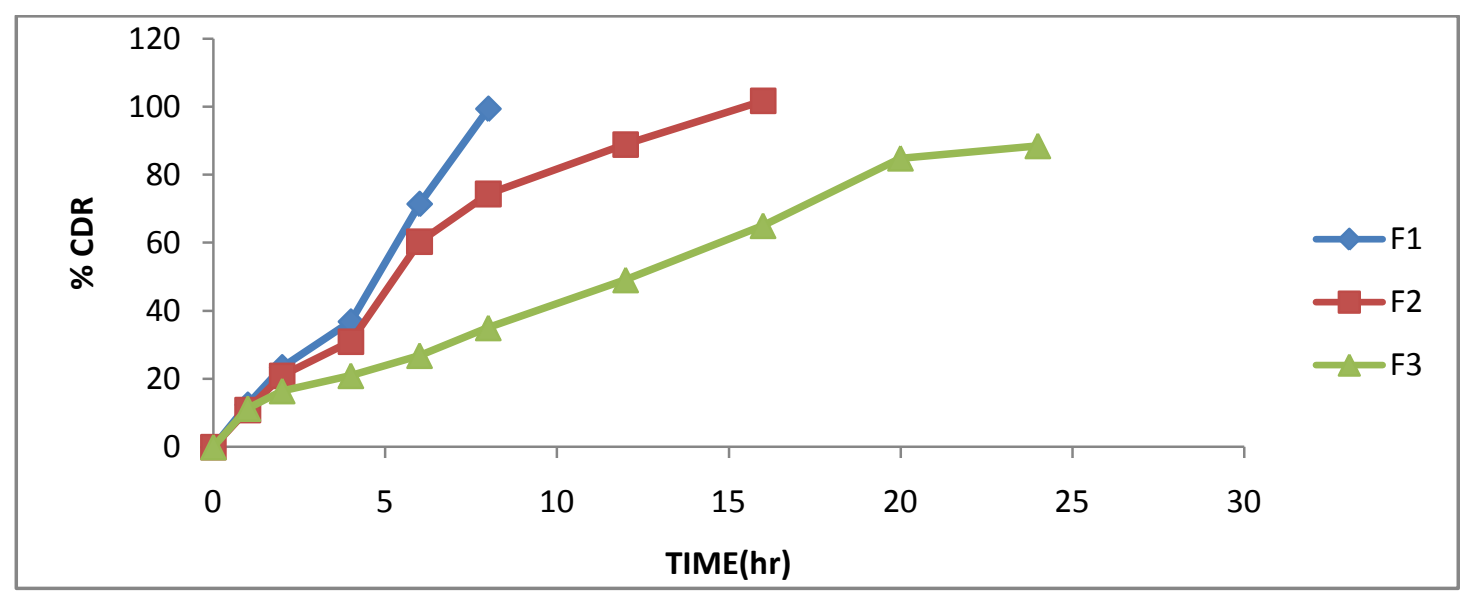

Figure 2: In Vitro Dissolution Study of Immediate release layer tablet F1 to F3

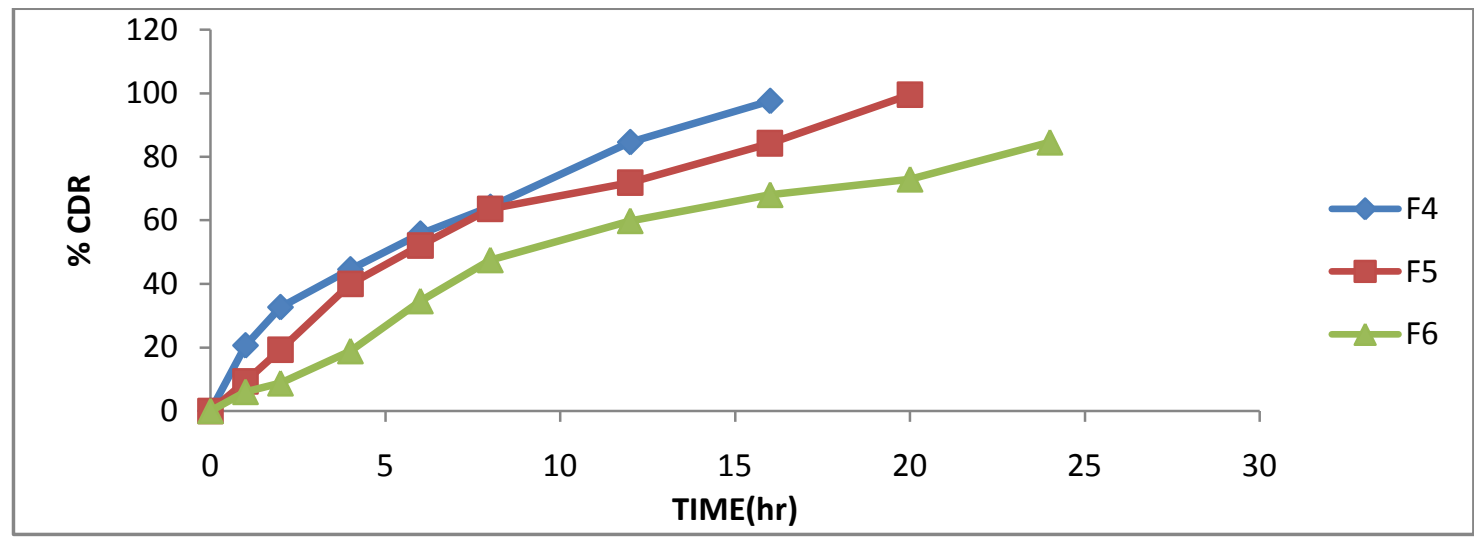

Figure 3: In Vitro Dissolution Study of Immediate release layer tablet F5 to F6 


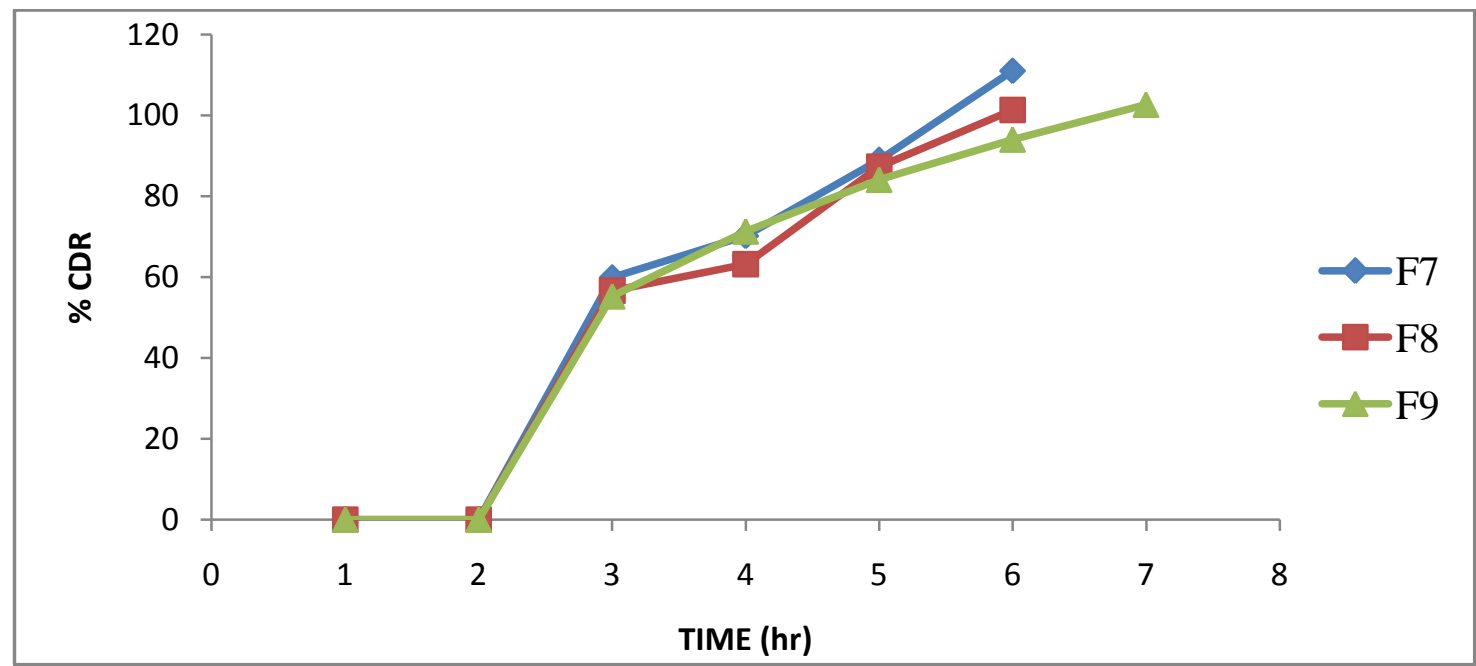

Figure 4: In Vitro Dissolution Study of Sustained release layer tablet F7 to F9

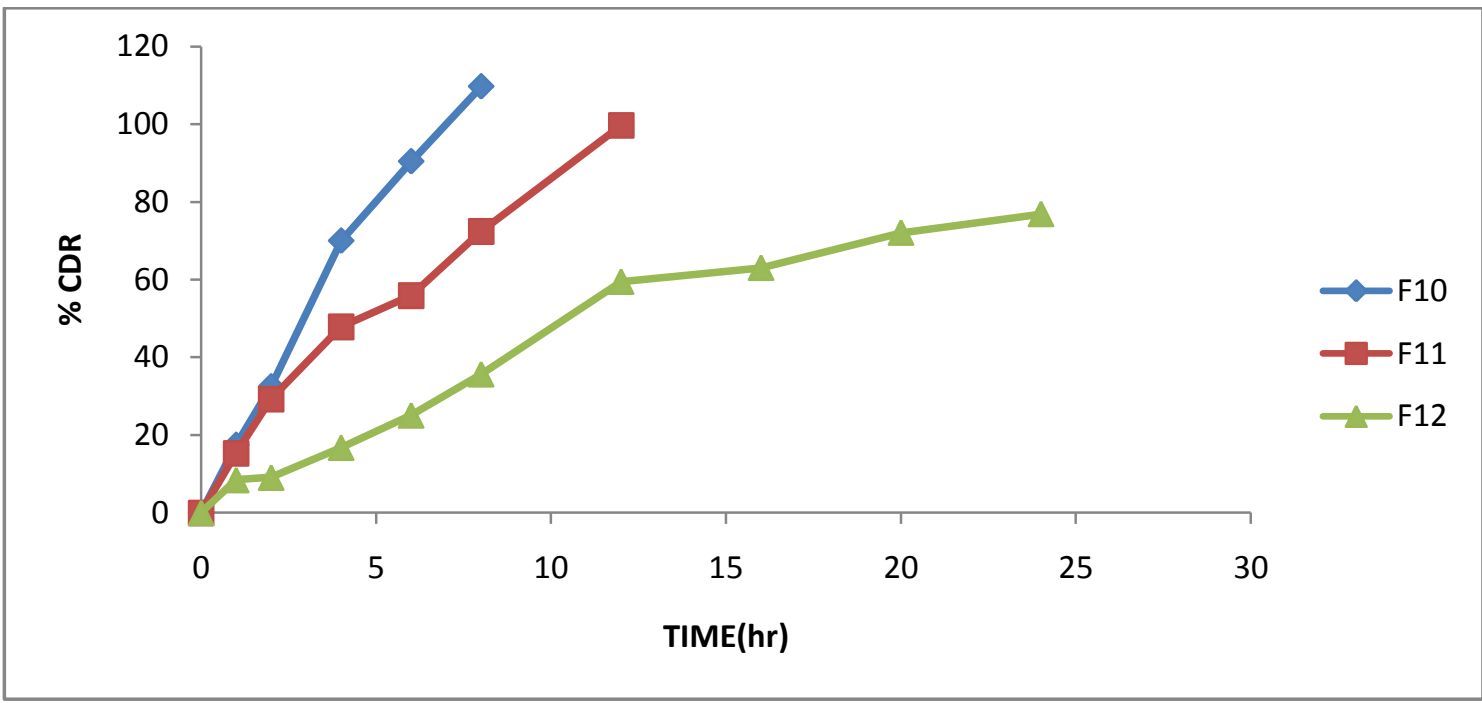

Figure 5: In Vitro Dissolution Study of Sustained release layer tablet F10 to F12

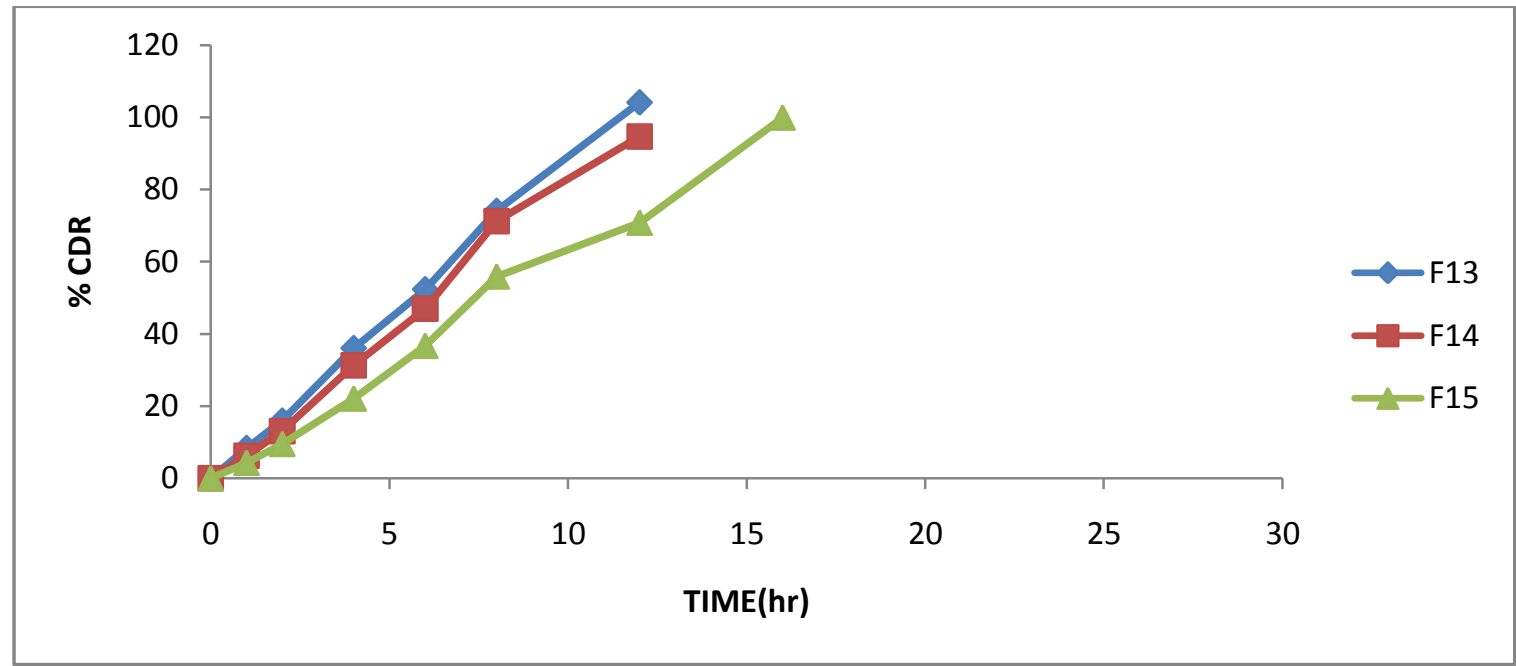

Figure 6: In Vitro Dissolution Study of Sustained release layer tablet F7 to F9 


\section{DISCUSSION}

In Bilayer tablet of Baclofen immediate release layer was prepared by direct compressionand sustained release was prepared by wet granulation method. The Tablets Containing PEO WSR 303 polymer showed the desired sustained action. Formulations $\mathbf{F 6}$ releases up to 24 hours and it shows good sustained action. In all the formulations an initial burst release was seen to provide the loading dose of the drug, followed by the controlled release. From these results it clearly indicates that the prepared formulations are potential of the Baclofen bilayer matrix tablet as an alternative to the conventional dosage form. Batch F7-F9 containing ethyl cellulose not shows the retardation of drug at lower concentration. Ethyl cellulose shows sustain action up to $8 \mathrm{hrs}$. HPMC different viscosity grades,

\section{REFERENCES}

1. Jha MK, Rahman MH and Rahman MM, "Biphasic oral solid drug delivery system: a review." Int. J. Pharm Sci and Res, 2 , 2011, 1108- 1115.

2. Kale SS, Saste VS, Ughade PL and Baviskar DT, "Bilayer tablet." Int. J. Pharm Sci and Res, 9, 2011, 25- 30.

3. Abebe A, Akseli I, Sprockel O, Kottala N, and Cuitino AM, "Review of Bilayer Tablet Technology." International. $J$. Pharmaceutics, $461,2014,549-558$.

4. Aggarwal S, Syan N and Mathur P, "Bilayer technologyopening new ways in drug delivery system: an overview." Int. J. Res. Pharm. Bio Sci, 4, 2013, 8-16.

5. Kumar AP, Pramodaganta, Bhoopathi SG and, Kulkarni SV, "Current Innovation in Layered Tablet Technology: Review." Asian. J. Res pharm. sci. 3,2013 189-194.

6. Yadav G, Bansal M, Thakur N, sargam and Khare P, "Multilayer tablets and their drug release kinetic models for oral controlled drug delivery system." Middle. East. J. Scientific Res, 16, 2013, 782- 795.

7. WWW. US. Elsevier health. Com//paper/chapter 12 Skeletal muscle relaxants.pdf

8. Kulkarni U, Vedpathak PA, Patil BS and Hariprasana RC, "Formulation and Evaluation of Bilayer Matrix Tablet of Baclofen Using Xanthan Gum. "Asian J. Biochemical. Pharm. Res, 2,2011, 464-472.

9. Remington, the Science and Practice of Pharmacy; $21^{\text {st }}$ Edn; pp. 1415.

10. Rekand T, "Clinical assessment and management of spasticity: a review.” Acta. Neurol. Scand, 122, 2010, 62- 66.
PEO WSR 303 and Carbopol 934 shows retardation of drug. A higher viscosity polymer shows desired retardation up to $24 \mathrm{hr}$.

\section{CONCLUSION:}

In vitro release studies demonstrated that the release of Baclofen from the prepared bi-layer matrix tablets were dependent on polymeric level. When we increased the polymeric concentration, due to this increased concentration of sustained release polymers drug release was retarded up to $24 \mathrm{hr}$. In all the formulations an initial burst release was seen to provide the loading dose of the drug, followed by the controlled release for $24 \mathrm{hr}$ From these results it clearly indicates that the prepared formulations are potential of the Baclofen bilayer matrix tablet as an alternative to the conventional dosage form.

11. Indian pharmacopoeia; Government of India Ministry of Health and Family Welfare; The Indian Pharmacopoeia Commission Ghaziabad; 2007, pp. 768- 771.

12. Roydan, Unitted State Pharmacopoeia;pp. 217- 218.2007.

13. Ahuja S, "Baclofen." Ciba. Geigy. Corporation, 14, 1975, 527- 548.

14. Maggi L, Machiste EO, Torre ML and Conte U, "Formulation of Biphasic Release Tablets Containing Slightly Soluble Drugs." European. J. Pharm. Bio pharm, 48,1999, 37-42.

15. Ahmad QJ, Hariprasana RC and Kulkarni U, "Design and Evaluation Twice Daily Lornoxicam Bi Layer Matrix Tablets By Using Hydrophilic Polymer Sodium Alginate. "Asian. J. Biochemical. Pharm. Res, 2,2011, 552-561.

16. Kumar HG, Jagannathan K, Sambath $R$ and Perumal $P$, "Formulation and Invitro Evaluation of Bilayer Floating Tablets of Metformin Hydrochloride and Sitagliptin Phosphate." Int. J. Advanced. Pharmaceutics, 2,2012, 64-81.

17. Jayprakash S, Mohamed HS, Kulathuran PK, Vignesh N, Mohmd Firthouse PU, and Bhoopathi M, "Formulation and Evaluation of Bilayer Tablet of Metformin Hydrochloride." Asian J. Pharm. Hea. Sci,1, 2011, 183-188.

18. Karwa $\mathrm{P}$ and Kasture PV, "Formulation and In Vitro Evaluation of Bilayer Tablet of Zolpidem Tartrate for Biphasic Drug Release." Int. J. PharmTech. Res, 3, 2011,1919-1929.

19. Yin L, He wei, Li Y, Zhang R and Wu Z, "Gastro Floating Tablets for the Sustained Release of Metformin and Immediate Release of Pioglitazone: Preparation and In Vitro/ In Vivo Evaluation.” Int. J. Pharm,476,2014, 223-231. 